\title{
SERBOCROATIAN-ENGLISH DICTIONARY
}

The research reported hercin was performed pursuant to a contract with the United States Department of Health. Education, and Welfare. Office of Education. Institute of International Studies, under the authority of Title VI. Section 602 NDEA.

Istraživanja o kojima je reč u ovoj knjizi bila su izvršena u vezi sa Ugovorom Zaključenim s Američkim Ministarstvom za Zdravlje, Obrazovanje i Soc. Staranje, Odsekom za Obrazovanje, Institutom za Medunarodni Naučni Rad, a na osnovu Glave VI, Dela 602 NDEA. 


\title{
SRPSKOHRVATSKO-ENGLESKI REČNIK
}

\author{
MORTON BENSON \\ UZ SARADNJU \\ BILJANE ŚLJIVIĆ-ŠIMŠIĆ
}




\title{
SERBOCROATIAN-ENGLISH DICTIONARY
}

\author{
MORTON BENSON \\ WITH THE COLLABORATION \\ OF \\ BILJANA SLLIVIĆ-ŠIMŠIĆ
}

UNIVERSITY OF PENNSYLVANIA PRESS 